\title{
RESEARCH ON THE DEGREE OF SUSTAINABILITY IN THE HUMAN RESOURCE MANAGEMENT IN TOURISM OF BRAŞOV MUNICIPALITY
}

\author{
Pascu Raphaela Ioana ${ }^{15}$ \\ Diana Foris ${ }^{16}$
}

\begin{abstract}
This research refers to the perception that human resource management has remained frozen over time in tourism industry, although this sector is under development. Other studies on this topic confirm employees complaints about poor pay, challenging conditions at work and few opportunities for growth and development. Change can take place at managerial level with the practice of a new, sustainable management. We wanted to identify, within a hotel unit, the current level of knowledge that managers have regarding sustainable human resource management and the degree of interest in the future application of sustainable practices. The hypotheses that we create are that the theory of sustainable management is not yet well known, therefore not so many practice it; that, it could be interest and managers would like to be better informed because this type of management brings positive results. We used a qualitative research, in which we helped with a semi-structured interview guide with open questions, responds with nominal scale, ordering scale or interval scale.We succeeded to find that half of our respondents do believe that sustainable management influence the quality of services, but a fair one is not applied, especially in tourism. Friendship, the relaxed relationship at work are the values that managers bet on when they think at sustainable management of people. They say that sustainable management is not enough to make loyal employees, but it can bring economic benefits in a long period of time. In short, this is an article that provides a view on the actual type of people management practiced in the tourism sector of Brasov and the posibility to improve it with the help of sustenability. Our work is important for creating a base in the development of human resource management, which is necessary to satisfy future customer needs.
\end{abstract}

Keywords: human resources management, human management trends, tourism, hotel management, sustainability, qualitative research.

\footnotetext{
${ }^{15}$ Faculty of Food and Tourism, Transilvania University of Brasov, Street Castelului, Romania

${ }^{16}$ Assoc. Professor Diana Foris, Faculty of Food and Tourism, Transilvania University of Brasov, email : diana.foris@unitbv.ro
} 


\section{INTRODUCTION}

Tourism, initially considered a green industry, has allowed millions of tourists to visit areas around the world. Hotels and resorts were built. Flights have multiplied and the ecosystem is affected slightly. As described in an anthropological article, tourism is a complex phenomenon that includes stakeholders and different processes (client tourist, companies and business people, intermediaries, laws and rules, technology, territories, resources, etc.). All this is a network that has become one of the largest industries (Mansilla, 2018). Recently this industry has been equated with pollution, climate change, land exploitation, protection of the natural and cultural environment, and this can create a crisis, so it is important to pay more attention to the environment. Sustainable Development is the concept that tries to reconcile these conflicts of interests: economic development and at the same time sustainable. Also in support of the concept of "sustainable" came the idea of positive tourism (for a better life here, on earth) and voluntary movement (voluntary tourism which plays an important role in social development). Sustainable tourism thus becomes a link between mass tourism, exploitation and ecology.

According to the UNWTO website (www.sdt.unwto.org) it is defined that sustainability in tourism takes into account the current and future economy, social and environmental impact, addressing the needs of visitors, industry, the environment and the host community. "The sustainable nature of tourism covers many aspects: responsible use of natural resources, taking into account the impact of activities on the environment (waste generation, pressure on water, soil and biodiversity, etc.), use of „clean energy, heritage protection and preserving integrity natural and cultural destinations, the quality and permanence of the jobs generated, the positive impact on the local economy or the quality of the reception "(Epuran, 2015). In the "White Paper on Business Sustainability" (July 2014), elaborated under the patronage of the World Economic Forum, it is admitted that businessmen / investors recognize the financial success and the survival of the company as "dependent on their contribution to the development of a clean environment and of human rights in the societies in which it operates".

The specialized literature refers to certain methods for the development of a sustainable society, and these are based on economic, social and environmental dimensions. (Svensson et al., 2018; Zhao et al., 2019). To make it easier to understand, there is talk of "social/societal responsibility", along with that of sustainable development. Social responsibility represents the company's contribution to sustainable development. Some firms comes to consider the effects of their best practices on the environment and society (Responsabilite societale des entreprises, 
2013). According to Danciu (2013) writing on Sustainable Enterprise, holism is the first principle that must be respected by the company and implies close and permanent relations between the components of sustainability in the face of challenges such as ecological, social and economic. The diversity of sustainability suggests the variety of different elements, strategies and solutions that give the company the ability to generate, produce, reproduce and evolve. The principle of interdependence takes into account the benefits obtained if the principle of holism and diversity are respected. People / companies can choose between continuing to exploit resources or renew and regenerate, while maintaining the sustainable ecosystem for future generations. Another principle described by the author of the work is the long term. "Slowing down and reversing the trend of degrading the quality of life and the environment are a matter of time. All efforts to improve sustainability must be long-lasting, permanent, to keep the company functioning while producing a profit, without endangering the well-being of future generations."(Danciu, 2013).

Modern society presents itself as a network of organizations that appear, develop or disappear. Under these conditions, people are a common source and, at the same time, a key resource of all organizations. Organizations involve people and depend on their efforts, becoming the very essence of any industry. "The reality that exists in the world-renowned companies shows that a company remains competitive only if it has an efficient management in the use of human resources. Within these resources, the individual performance must be high enough for the organization to achieve excellence. Individual performance depends on the motivation system, the employees' willingness to make the necessary effort in the work, on the training and training of the employees, as well as on their ability to execute what is required of them (Albu, Moroşan-Dănilă, 2007) . Sustainable strategies mean adjustments on the part of organizational culture, work system, work behavior, it even includes the way employees see the company they work for. In this context, companies must respond to the idea of sustainability at all levels, transforming the human resource into employees who contribute both to the internal environment (effectively in the company) and to the external environment (community, family, environment).

\section{SUSTAINABLE HUMAN RESOURCES MANAGEMENT}

Sustainable management of human resources means maintaining positive relationships between employees, is attractive to the internal and external environment, offers incomes depending on the involvement and value of the employees and the work they do, accepts interaction with potential employees and is efficient. In the field of tourism, in order to ensure the sustainability of the ecological natural environment, a sustainable human resource management has the capacity to contribute by educating the visitors for a responsible attitude towards the natural environment. At the same time, the human resource from tourism can directly participate in the protection of 
some natural resources around the units in which they work, can watch over those who are in danger and inform tourists about them. Equally important, in the existing tourist units, is the importance given to recycling, the use of renewable energy, and others (Mihalic, Gartner, 2013).

Economic sustainability is the need to maintain a permanent income for the employees, creating a capital that does not run out. On the social sustainability side, the management of human resources can contribute to the creation of new jobs, care of work accidents, harassment of employees, human rights abuses, and others.

A sustainable work system is a work system in which the quality of work (ie employee health, well-being and personal development), the quality of the organization (productivity, efficiency, the ability to face the challenges) and the quality of connections with the environment (both nature and society) are kept at a high level. Behind this type of management are two development strategies, namely planning for success and maintaining market competitiveness. The stages to be followed when discussing talent management are planning, attracting, developing and maintaining (Neacsu, 2010). Sustainable work could be a step in the evolution of professional life. Another part of human resource management, in a sustainable way, is talent management. The employee's hidden qualities can put the company name in the spotlight and each employee has his own talent. Employees also want to discover their talent and be benefited by the company (Penttila, 2007). To summarize, we can say that talent management is the commitment of an organization to discover, attract, hire, maintain and develop the most talented employees available in the labor market.

What makes sustainable management particularly important is its orientation towards preserving resources for as long as possible, looking for solutions that improve the company's image without inadequately exploiting resources, including human resources. Sustainability becomes a way of thinking and acting in the company. "Only this way can companies contribute to the development of leaders with a holistic thinking, who understand the economic and socio-ecological system in which their organization operates. Leaders who succeed in inspiring people in the company to contribute to a bigger cause that goes beyond financial targets "(Tetelea, 2019).

In this regard, we wanted to find out to what extent the people who run activities at the hotel level know the concept of sustainable management of the human resource, if in practice they manage to apply the acquired knowledge or would like to find out more information about this field.

\section{RESEARCH METHODOLOGY}

This study is intended to eliminate existing misconceptions, correct mistakes if they exist, and add new knowledge to the existing background. In this sense it is necessary 
to know the current stage, to get in touch with competent managers in the field of tourism. For this I used a method of interviewing, namely the interview guide, which, together with the observation method, is one of the main ways of approaching reality in qualitative research. The specificity of the qualitative interviews consists mainly in the use of open and focused questions.

We chose to apply the knowledge related to qualitative research based on the assumption that people attach certain meanings to the world they live in, different from one person to another. The qualitative method offers the possibility of a deeper understanding of the human subject. The main purpose of the research is to find out the truth that is hidden and which has not yet been discovered, by applying the scientific procedure.

The interview guide used in the present research is semi-structured, the topic was known and some questions were asked, however, during the interview there were times when new questions were created. 13 standard questions were used based on which the discussion will be conducted with the respondents willing to participate in our research. We chose as a sampling strategy the rational one (the cases are chosen by the researcher, depending on the relevance estimated in relation to the research topic), being for the benefit of the research the choice of qualified respondents, on administrative positions, who have subordinate human resources. The respondents are persons between the ages of 30 and 50 years, having management positions in hotel units, with more than 2 subordinate people and experience in human resource management. The variability of the studied cases is small, the area from which we chose the sample being a single hotel unit, namely the Aro Palace Hotel, 5 stars.

The research was carried out in the field, at the workplace of the interviewed persons, more precisely in the premises of the Aro Palace hotel, 5 *, Braşov. Aro-Palace S.A. Commercial Company. Brasov is a recognized leader in the domestic and international tourism market, through accommodation and public catering services to a high quality standard.As written on the website www.icar.ro,it offers a wide range of tourist services, you can choose any degree of comfort for the accommodation units it manages: 5 stars at Hotel Aro Palace, 3 stars at Hotel Capitol, 2 stars at Hotel Coroana. To meet the clients they come with a variety of menus offered by a Romanian and European cuisine. Their offer also includes space for Wellness and SPA, ozone therapy sessions, etc. We chose this environment and place because they are important elements in getting the most concrete answers. I took into account the fact that people need a known environment in which to feel safe.

Our main objectives refer to the application of sustainable management on the human resource, in the field of tourism. A good understanding of this topic can bring real benefits to the development of the tourism industry. In table 1 we set out the questions 
from which we started in constructing the interview, questions that the researchers follow regarding the studied subject:

Tab. 1. Basic aspects, questions and objectives

\begin{tabular}{|c|c|c|}
\hline Basic aspects & Researcher's questions & Objectives \\
\hline $\begin{array}{l}\text { If the concept of } \\
\text { sustainable human } \\
\text { resource management in } \\
\text { tourism is known }\end{array}$ & $\begin{array}{l}\text { 1. What is meant by the } \\
\text { sustainable management of } \\
\text { the human resource in } \\
\text { tourism? } \\
\text { 2. Do you have good practice } \\
\text { models in the field of } \\
\text { sustainable management? }\end{array}$ & $\begin{array}{l}\text { O1. Identification of the level } \\
\text { of knowledge in the concept } \\
\text { of sustainable management of } \\
\text { the human resource in Brasov } \\
\text { tourism. } \\
\text { O2. Identify how the concept } \\
\text { of sustainable management in } \\
\text { the human resource in Brasov } \\
\text { tourism is seen. }\end{array}$ \\
\hline $\begin{array}{c}\text { The importance attached to } \\
\text { this concept in a hotel in } \\
\text { Brasov }\end{array}$ & $\begin{array}{l}\text { 1. What is the efficiency } \\
\text { perceived inside a Brasov } \\
\text { hotel regarding the } \\
\text { implementation of a } \\
\text { sustainable management of } \\
\text { the human resource? } \\
\text { 2. What are the resources that a } \\
\text { Brasov hotel would be } \\
\text { willing to dedicate to the } \\
\text { implementation } \\
\text { sustainable human resource } \\
\text { management? } \\
\text { 3. What would be the frequency } \\
\text { of your requests? } \\
\text { What value does the } \\
\text { administrative attribute of } \\
\text { learning these sustainability } \\
\text { principles? }\end{array}$ & $\begin{array}{l}\text { O1. The degree of interest } \\
\text { identified within a hotel in } \\
\text { Brasov, on the sustainable } \\
\text { management of the human } \\
\text { resource. } \\
\text { O2. The contribution of the } \\
\text { sustainable management of } \\
\text { the human resource to the } \\
\text { economic development of a } \\
\text { hotel in Brasov }\end{array}$ \\
\hline $\begin{array}{c}\text { The short and long term } \\
\text { interest in implementing a } \\
\text { sustainable management of } \\
\text { human resources }\end{array}$ & $\begin{array}{l}\text { 1. Is there an interest in } \\
\text { implementing sustainable } \\
\text { management? } \\
\text { 2. What are the most attractive was } \\
\text { implement a sustainable huma } \\
\text { resource management? }\end{array}$ & $\begin{array}{l}\text { O1. Their interest and } \\
\text { availability in implementing a } \\
\text { sustainable program } \\
\text { O2. Attractive } \\
\text { implementation possibilities } \\
\text { for managers. }\end{array}$ \\
\hline
\end{tabular}

Source: provided by the authors.

What we are going to highlight is whether the management practiced is a sustainable one, which is the importance given to the practice of this type of management and which is the current stage of knowledge of the managers regarding the specialized theory in the field. 


\section{RESULTS AND DISCUSSIONS}

We managed to collect the data exactly as they were exposed by the interviewees. After applying the 4th interview, I noticed that the information started to repeat or resemble each other, that is, the theoretical saturation was reached. All the answers received from the interviewees were recorded in a database. The analysis of the results was a horizontal one, which indicates how each category, topic, is approached by all respondents. With the help of the quantitative research method, it was allowed to reach the proposed objectives, namely to identify the current state of knowledge of the sustainability field among managers, the importance of such a concept of sustainability among the tourism of Brasov and the interest towards the implementation of a new sustainable program.

In order to present the relevant information in a structured way, the results are grouped on the basic aspects of the research.

\section{If the concept of sustainable human resource management in tourism is}

\section{known}

The most relevant information, put in order, gives us the conclusion that managers have knowledge about sustainable management. The first four questions of the semistructured interview had positive answers and confirmed the managers' knowledge regarding sustainable management. Both theoretical and practical. Question number 5, namely "How do you manage to apply sustainable management in practice? "Revealed different sustainable working methods in the relationship with the employees. The respondent identified with the number 2 (function of commercial director) in the list of respondents, described his answer as follows: "We have prepared performance sheets, we keep in control the way the people in my subordinate do their job, I constantly check the space that I manage. , the people who work there, understand, learn, motivate the employees, think about solutions to improve their daily work".

\section{The importance attached to this concept in a hotel in Brasov}

Half of our respondents believe that sustainable management influences the quality of services and in this area has the greatest impact. The quality rate (created as a result of customer feedback) is among the most important values of any work process, which gives added importance to sustainable management.

Two respondents out of the four consider that in Romania no proper sustainable management is applied, especially when it comes to tourism, some mention. When we talk about sustainable management, we are talking about multi-level development, we are talking about strong values and principles that go beyond our own selfishness to be part of a complex body that is the company. In Romania, it seems that these principles 
are not fully integrated in the conception of the employees, and this creates a more difficult job for their managers.

The friendship, the relaxed relationship from the workplace are the values that managers bet on when referring to the sustainable management of the human resource, and from here begins its application. If you start from a good relationship with subordinate employees, you can already see them with other eyes and by default you can judge them less and understand more. Regarding the 7th question, namely employee loyalty after applying sustainable management, the managers who participated in the research do not recognize a great success in retaining the employees only based on the principles of sustainable management. However, through the medium and long term approach, it can bring economic benefits by reducing staff turnover and through quality services that will attract tourists.

1. The short and long term interest regarding the implementation of a sustainable management of the human resource

This research could be open for trainers who want to diversify their range of courses, given that interviewed managers were open to the idea of studying this branch of the future: sustainability, applied to human resource management. The last 4 questions of the interview are related to managers' preferences for possible learning methods that could be offered to them in order to improve their management skills in a sustainable manner. The respondents were delighted with the idea of training, especially in the conditions where they could be held in another place than the workplace and would involve various learning activities. In addition, the amount is not a problem if the training is paid by the employer.

In order to be able to support our hypothesis that it represents a real value to know the principles of sustainable management of the human resource, we asked the managers. The choice is a clear one, all the respondents chose the answer yes to the question regarding the economic benefits to the company. I continued the series of questions, to find out more details about what these people prefer regarding the possible trainings. The most appreciated method of learning remains the one with a personal mentor and practical experiences in the workplace. Among these managers, who assume that they spend a good amount of time studying on their own, solving problems and recording data, a good learning method is the active one, in which they are involved in other activities than the daily ones. The vast majority of respondents recommend an interactive course, with exchanges of ideas, good practices, communication, even free offers and offers, some say. 


\section{CONCLUSION}

In most cases, managers do not take into account all dimensions of sustainable development, few are those who make efforts and simultaneously address all three components: environmental, economic, social. However, the need to stimulate innovation and create conditions for sustainable growth is well recognized in Europe. Therefore, alignment with the standards of developed countries is recommended, which also recommends the introduction of sustainable human resource management in the field of tourism.

This concept of sustainability should not only relate to the relationship between manager and employee, but companies must respond to the idea of sustainability at all levels, transforming the human resource into employees that contribute to the internal (effectively in the firm) and external ( community and family) or environment. The purpose of the human resource becomes the development of a sustainable business. The main value can be added to the quality of the services offered by employees who perceive their work, as one that needs attention and who offers this attention with care, because they are respected by managers who start with thoughts of friendship in forming collegial relationships.

This study can be of theoretical help for other researchers who can discover other details of sustainable management, continuing the series of interviews in other hotel units, leisure and food units. Regarding the practical part, research can become a basis for hotel managers, HR managers in hotels, as well as certain professional schools who wish to adapt their educational offer. The sustainable management of the human resource is a subject that can be studied further, so that new methods, strategies for applying this management can be discovered in the future. At the same time the subject can continue with a research in the field of psychology, to discover how the tourism employees adapt to the work schedule, the specific conditions and, at the same time, to be offered benefits and a different motivation depending on the status that everyone in the company have.

It is necessary to improve the current knowledge of sustainable management of the human resource in the hotel field, an aspect that is observed from the desire of the managers to participate in paid trainings by the company, where they can exchange ideas with specialized people, from whom they can learn how to apply in a practical way the knowledge eventually with a personal mentor. 


\section{REFERENCES}

1. Albu, O. \& Moroşan Danila, L. (2007). Tendinte si provocari in Managementul Resurselor Umane Internaţionale, Conference paper

2. Danciu, V. (2013). Întreprinderea sustenabilă. Noi provocări și strategii pentru îmbunătățirea sustenabilităţii corporative. Economie teoretică şi aplicată, Volume XX, No. 9(586), 4-24

3. Epuran, G., Dovleac, L., Ivasciuc, I.S. \& Tescașiu, B. (2015). Sustenability and Organic Growth Marketing: an Exploratory Approach on Valorisation of Durable Development Principles in Tourism. Amfiteatru Economic, 17(40), 927-937

4. Mansilla, J. A. (2018). Reflections about Tourism as a Total Social Fact. Global Journal of Archaeology and Anthropology. ISSN: 2575, 8608, Volume 6(5), 1.

5. Mihalic, T. \& Gartner, W. (2013). Tourism and Developments. Issues and Challenges, NOVA Publisher.

6. Neacsu, V. (2010). Newspaper Marchet Watch Svensson, G., Ferro, C., Høgevold, N., Padin, C., Varela, J. C. S. \& Sarstedt, M. (2018). Framing the triple bottom line approach: direct and mediation effects between economic, social and environmental elements. Journal of Cleaner Production, 197, 972 991.

7. Penttila, C. (2008). Talent Scouting: Staff Smarts, http://www.findarticles.com/p/articles/mi_MODTI/is-5-32/ai_n6023867

8. Responsabilite societale des enterprises (2013). www.developpement-durable". Gouv.fr/Responsabilite-societale-des.html/

9. Tetelea, I. (2019). Drumul către un business sustenabil începe cu angajații companiei. Invisible Nature. Retrieved from https://www.invisiblenature.ro/sustainable-business/drumul-catre-un-businesssustenabil-incepe-cu-angajatii-companiei/

10. Zhao, L., Zha, Y., Zhuang, Y. \& Liang, L. (2019). Data envelopment analysis for sustainability evaluation in China: Tackling the economic, environmental, and social dimensions. European journal of operational research, 275(3), 10831095

11. https://icar.ro/Hotel-Aro-Palace-Brasov-227.html

12. http://www.marketwatch.ro/articol/6640/Managementul_talentului/

13. https://sdt.unwto.org/content/about-us-5 